\title{
PALM HARVESTING AFFECTS SEED PREDATION OF Euterpe edulis, A THREATENED PALM OF THE BRAZILIAN ATLANTIC FOREST
}

\author{
PIZO, M. A. ${ }^{1}$ and VIEIRA, E. M. ${ }^{2}$ \\ ${ }^{1}$ Departamento de Botânica, Universidade Estadual Paulista, UNESP, C.P. 199, \\ CEP 13506-900, Rio Claro, SP, Brazil \\ ${ }^{2}$ Laboratório de Ecologia de Mamíferos, Centro 2, Universidade do Vale do Rio dos Sinos, UNISINOS, \\ Av. Unisinos, 950, C.P. 275, CEP 93022-000, São Leopoldo, RS, Brazil \\ Correspondence to: Marco A. Pizo, Departamento de Botânica, Universidade Estadual Paulista, \\ UNESP, C.P. 199, CEP 13506-900, Rio Claro, SP, Brazil, e-mail: pizo@rc.unesp.br \\ Received December 6, 2002 - Accepted April 17, 2003 - Distributed August 31, 2004
}

(With 1 figure)

\begin{abstract}
The palm tree Euterpe edulis is endemic to the Atlantic Forest, where it constitutes an economically important forest product. The often unplanned and illegal harvesting of palm hearts has led to drastic reductions in the populations of E. edulis in many areas where this palm used to be the dominant understorey tree species. We investigated the effects of harvesting on seed and seedling predation of E. edulis. We tested the predictions of the dominance-predation hypothesis according to which predator satiation leads to an inverse relationship between the amount of predation and the dominance of a tree species. During two consecutive years, seeds were set experimentally on an unharvested (> 250 adult palms/ha) and a neighboring harvested site (few, if any, adult palms) located in the Atlantic Forest of SE Brazil. Seedling mortality was studied at both sites for a six-month period in each of two consecutive years. Seed predation caused by rodents was higher at the harvested site, while insects caused more damage to seeds placed at the unharvested site. The proportion of seeds preyed upon by rodents varied annually, while insect predation did not. Seedling mortality did not differ between harvested and unharvested sites. The dominance-predation hypothesis was confirmed for generalist rodent seed predators, but not for specialist insect predators. This result shows that densitydependent mortality, not only at the individual level but also at the population-level scale, is a function of the class of predators and their types of foraging behavior.
\end{abstract}

Key words: Atlantic Forest, Euterpe edulis, harvesting, seed predation.

\section{RESUMO}

\section{Extração de palmito afeta a predação de sementes de Euterpe edulis, uma palmeira ameaçada da Mata Atlântica}

O palmito-jussara, Euterpe edulis, é uma árvore endêmica da Mata Atlântica e constitui-se em produto extrativista economicamente importante. A exploração ilegal e descuidada do palmito tem levado a drásticas reduções em suas populações ao longo de toda sua distribuição, que outrora fora abundante. Neste estudo investigamos o efeito da extração do palmito sobre a predação de suas sementes e plântulas por roedores e insetos. Especificamente, testamos a hipótese segundo a qual, em razão da saciação dos predadores, deve haver relação inversa entre a magnitude da predação sobre as sementes e a abundância da planta em determinada área. Durante dois anos consecutivos, sementes de E. edulis foram colocadas em uma área preservada (> 250 indivíduos adultos de E. edulis/ha) e em uma área vizinha explorada com baixíssima densidade de plantas adultas, ambas localizadas na Mata Atlântica do Estado de São Paulo. A mortalidade das plântulas foi estudada e comparada entre ambas as áreas por um período de seis meses. A predação das sementes por roedores foi maior na área explorada que na área preservada e variou entre os anos. A predação por insetos foi maior na área preservada e não variou entre os anos. A mortalidade das plântulas foi similar em ambas as áreas. A relação inversa 
entre a abundância da planta e a predação de suas sementes foi confirmada para predadores generalistas (roedores), mas não para predadores especializados (insetos). Os resultados mostram que a mortalidade de sementes dependente de densidade, não apenas em nível individual, como já demonstrado, mas também em escala populacional, depende do tipo de predador considerado.

Palavras-chave: conservação, Euterpe edulis, Mata Atlântica, predação de sementes.

\section{INTRODUCTION}

The palm Euterpe edulis Martius is endemic to the Atlantic Forest (Henderson et al., 1995) and constitutes an economically important forest product (Galetti \& Fernandez, 1998). Unlike the multistemmed E. oleracea from the Amazon basin, which permits the extraction of selected stems year after year, the harvesting of the palm heart (i.e., the edible apical meristem) from the single-stemmed $E$. edulis results in the death of the plant. This is because, once cut, it is unable to sprout. Thus, sustainable exploitation of E. edulis depends upon regeneration from seeds.

Despite being one of the dominant understorey plant species in many Atlantic Forest sites (Siqueira, 1994), the overexploitation of E. edulis, mainly by illegally-established factories, has led to its virtual disappearance from many areas. Nowadays, over a great part of its range, E. edulis is found only in protected reserves which are, however, frequently invaded by illegal poachers (Galetti \& Chivers, 1995). All of these put the once abundant $E$. edulis in a vulnerable position (Dransfield et al., 1988).

When conducted in an unmanaged way, harvesting of forest plant species may drastically reduce their populations, with important consequences for species interactions (Bawa \& Seidler, 1998), among them the interaction between the harvested plant and its seed predators. Several studies have tested and confirmed the predictions of the dominance-predation hypothesis, according to which there is an inverse relationship between the amount of seed predation and the dominance of a tree species (Boucher, 1981; Smith, 1987; Smith et al., 1989; Forget, 1992; Schupp, 1992; Cintra, 1997; but see McKee, 1995). In areas where the plant species in question occurs in high density, seed predators are satiated by the great amount of seeds produced, thus increasing the mean probability of seed survival. But if harvesting greatly reduces the population of that species, the relationship may be altered, leading to unusual levels of seed predation as well as changes in the pattern of plant recruitment (Smith, 1987).

In this paper we tested the dominance-predation model for E. edulis seeds and seedlings experimentally set in one harvested and one unharvested site differing greatly in E. edulis density. We predicted that, due to predator satiation at the unharvested site, seed predation would be more intense at the harvested site. Because rodents and insects usually differ in their response to the characteristics and overall availability of seeds (Hammond \& Brown, 1998; Notman \& Gorchov, 2001), we tested this prediction separately for each of these two categories of seed predators.

\section{Natural history background}

Euterpe edulis is widespread in the Atlantic Forest, inhabiting the coastal forest from $15^{\circ} \mathrm{S}$ to $29^{\circ} \mathrm{S}$, penetrating into the interior through gallery forests, and ultimately reaching Paraguay and Argentina (Henderson et al., 1995). Siqueira (1994) detected the presence of E. edulis in $49 \%$ of the 63 Atlantic Forest community studies she surveyed. Each individual of E. edulis produces 1-5 infructescences annually and bears an average of over three thousand fruits each (Mantovani \& Morellato, 2000). Fruits are globose drupes containing a single seed (mean \pm $\mathrm{SD}=13.5 \pm 1.3 \mathrm{~mm}$ length, $14.2 \pm 1.2 \mathrm{~mm}$ width, $\mathrm{n}=10$ ) covered by a thin black pulp. Fruit maturation period in the study areas extends from April to September, peaking in June-July (Galetti et al., 1999). Under shade house conditions, seeds started germination in 20-25 days (M. A. Pizo, unpubl. data), but in the field seeds may take longer to germinate (e.g., on average 118 days according to Matos \& Watkinson, 1998). During the 1996 fruiting season, E. edulis was responsible for $17 \%$ (September) to $98 \%$ (May) of monthly fleshy fruitfall (in terms of fresh weight) at the unharvested site (Galetti, 1996; M. A. Pizo, unpubl. data).

The fruits of E. edulis serve as food for a variety of fruit-eating vertebrates, including large mammals (e.g., tapirs; Rodrigues et al., 1993), bats 
(Faria, 1996), rodents (E. M. Vieira, unpubl. data), lizards (e.g., Tupinambis merianae; Reis, 1995), and birds. Twenty-five bird species were recorded eating the fruits of E. edulis at Parque Intervales, including the highly endangered Black-fronted Piping-guam or Jacutinga Pipile jacutinga, the Bluebellied Parrot Triclaria malachitacea, and the Cinnamon-vented Piha Lipaugus lanioides (Laps, 1996; Galetti \& Aleixo, 1998; Galetti et al., 1999). According to Collar et al. (1992), the elimination of $E$. edulis from extensive areas represents a sizable threat to the survival of these three bird species, which rely heavily upon its fruits, an assertion recently questioned by more detailed studies (Galetti et al., 1997; Galetti \& Aleixo, 1998).

Post-dispersal predation of E. edulis seeds is caused by a scolytid beetle (Coccotrypes palmarum Eggers 1933, Scolytidae) and rodents (Pizo \& Simão, 2001). Adults of $C$. palmarum were present in $96.6 \%$ of the 268 insect-attacked E. edulis seeds collected at both sites, the remainder being infested by an unidentified insect larva. Seeds of E. edulis offered to non-starved rodents in captivity were completely eaten by Nectomys squamipes and Oryzomys intermedius, the two most abundant rodents at the study sites (Vieira, 1999). Both these species are diet generalists, being able to eat fruits and seeds of several species and invertebrates as well (Emmons \& Feer, 1997; E. M. Vieira, unpubl. data). According to Reis (1995), several agents may cause mortality in E. edulis seedlings, including fungus, mollusks, insect larvae (e.g., the butterfly Antirrhaea archaea, Morphinae), and peccaries (Tayassu tajacu).

\section{STUDY SITES}

The harvested and unharvested sites chosen were located in the lowland Atlantic Forest of the municipality of Sete Barras, São Paulo State, southeast Brazil. The Parque Estadual Intervales (Saibadela Research Station; $24^{\circ} 14^{\prime}$ S, $48^{\circ} 04^{\prime} \mathrm{W}$ ), a 49,000 ha reserve, constituted the unharvested site. Saibadela Station presents a dense populaton of $E$. edulis (255.6 plants [dbh $>5 \mathrm{~cm}$ ] ha-1; AlmeidaScabbia, 1996), relatively undisturbed by illegal harvesting (but see Galetti \& Chivers, 1995). The harvested site was established on privately owned land $1 \mathrm{~km}$ distant from the unharvested site and separated from it by the Saibadela River, a small stream, and a 100-300 m wide strip of pastures and banana plantation. The total area covered by the harvested forest is difficult to estimate, but certainly comprises several hundred hectares (for more details about the two sites see Galetti \& Aleixo, 1998; Aleixo, 1999). At the harvested site illegal palm harvesting is frequent, resulting in a very low density of adult $E$. edulis palms. As a consequence of the contrasting adult $E$. edulis density, harvested and unharvested sites differ greatly in seedfall ( $0 v s .10 .5$ seeds $\mathrm{m}^{-2}$, data for the 1995 fruiting season; M. A. Pizo, unpubl. data), and seedling density ( $0 v s .2 .3$ seedlings [ $<30 \mathrm{~cm}$ height $] \mathrm{m}^{-2}$, respectively; $\mathrm{M}$. A. Pizo and E. M. Vieira, unpubl. data).

The region received a mean annual rainfall \pm SD of $4216.2 \pm 245.5 \mathrm{~mm}$ between 1994-96. Rains are well distributed throughout the year with no month receiving less than $100 \mathrm{~mm}$, but a period of less intense and less frequent rains happens between April and August. During this period, low temperatures may occur but rarely dropping below $10^{\circ} \mathrm{C}$ (mean $\pm \mathrm{SD}=20.8^{\circ} \pm 2.5^{\circ} \mathrm{C}$ for the study period), in contrast with the wetter period when maximum temperature may reach $42^{\circ} \mathrm{C}\left(25.7^{\circ} \pm 2.8^{\circ} \mathrm{C}\right)$. Oldgrowth forest (sensu Clark, 1996) predominates in both sites. The understorey is open and the canopy is $25 \mathrm{~m}$ in height with a few emergent trees reaching $30 \mathrm{~m}$ (Almeida-Scabbia, 1996).

\section{METHODS}

\section{Seed predation}

The effects of palm harvesting on post-dispersal seed predation of $E$. edulis were investigated in JuneJuly of 1996 and 1997 by setting seeds on two parallel, $300 \mathrm{~m}$ long transects established at the harvested and unharvested sites, and then recording the number of seeds that had been preyed upon by rodents and insects one month later. The parallel transects with 30 experimental stations each were set 2-3 m off-trail on opposite sides of the trails crossing the two sites. Stations were $10 \mathrm{~m}$ distant from the next station on the same transect, and at least $5 \mathrm{~m}$ from the nearest station on the opposite parallel transect. Each station received five seeds, totaling 300 seeds (60 stations $x$ 5 seeds per station) at each site each year. The seeds used on the transects had been regurgitated by birds and collected in the field. To be sure that the disappearance of seeds from the stations was in fact due to removal by rodents and not washed away by heavy rains, we cemented individual seeds with epoxy resin to $20 \mathrm{~cm}$ pieces of $4.7 \mathrm{~kg}$ fishing lines. The opposite ends of the lines were then tied to saplings 
at each station. This method has been used by other authors (e.g., Schupp, 1988) with no apparent effect on seed exploitation by rodents. We considered to have been removed (and possibly preyed upon) by rodents every seed not found attached to the fishing line. Insect predation was verified by looking for the typical entrance hole left by beetles entering the seeds. It is important to note that, unless rodents avoid insectinfested seeds, a possible but presently unavailable information (see Sallabanks \& Courtney, 1992), we may have underestimated insect predation, because insect-infested seeds might have been removed by rodents prior to our censuses.

Data obtained with the aid of spool-and-line devices (as described by Boonstra \& Craine, 1986; Key \& Woods, 1996) in the same study area indicated that the probability of a food item being found by rodents does not increase with the presence of another food source placed 5-10 m (E. M. Vieira, unpubl. data). Thus, seed stations were considered independent of each other. The seed predation data were not normally distributed, thus we used the Friedman two-way block test (Sokal \& Rohlf, 1981) to explore the main effects of the independent variables (harvesting regime [i.e., harvested $v s$. unharvested] and year) on the dependent ones (proportion of seeds preyed upon by rodents and insects). We first asked if the harvesting regime had an effect upon seed predation when data were blocked by year, and then asked if year had an effect when data were blocked by harvesting regime. MannWhitney tests were used to identify site differences in the combined proportions of seeds preyed upon by insects and rodents. Values presented refer to medians and first-third quartile ranges.

\section{Seedling mortality}

To investigate the possible effect of palm harvesting on seedling mortality, in August 1996 we planted seeds in plastic trays filled with sand and kept in a sheltered green house (25\% full sunlight) constructed at Saibadela station especially to nurse E. edulis seedlings. In November 1996, the newly-germinated seedlings (approximately $6 \mathrm{~cm}$ in height, with the still-closed leaves pointing upright) were transplanted to the parallel transects established for the seed-predation study at both harvested and unharvested sites.

Each station received one seedling whose position was marked with a colored flag. We monitored seedling survival at 1,2, 4, and 6 months after transplanting. Since we were unable to assign a mortality agent to all seedling deaths, analyses were performed by pooling the data irrespective of mortality agent, except for one seedling killed by branch fall at the unharvested site. The hypothesis that seedling survival differed between harvested and unharvested sites was tested with a $2 \times 2$ contingency table constructed with the total number of seedling deaths recorded at the end of the study (i. e., six months after transplanting).

\section{RESULTS}

The harvesting regime significantly affected rodent and insect predation, but in opposite directions (Table 1, Fig. 1). Overall, predation caused by rodents presented slightly higher values at the harvested site than at the unharvested one (median of the proportion of preyed upon seeds/station plus first-third quartile range, both years pooled: 0.0, 0.00.2 vs. $0.0,0.0-0.0$ for the harvested and unharvested sites, respectively), while insects caused more damage to the seeds placed at the unharvested site (0.2, 0.0-0.2 vs. 0.0, 0.0-0.2, respectively). In addition, the proportion of seeds preyed upon by rodents was affected by year; a slightly higher proportion of seeds were preyed upon in 1996 (0.0, 0.0-0.2; both sites pooled) when compared to 1997 $(0.0,0.0-0.0)$. Insect predation, in contrast, was not affected by year (0.1, 0.0-0.2 and 0.0, 0.0-0.2 for 1996 and 1997, respectively; Table 1).

The combined proportion of seeds damaged, either by rodents or insects, between harvested and unharvested sites, did not differ either in 1996 (0.27 vs. 0.20, respectively; $\mathrm{U}=1.74, \mathrm{p}=0.08$ ), or in 1997 (0.20 vs. $0.22 ; \mathrm{U}=1.54, \mathrm{p}=0.12$ ).

Six months after transplanting, $20.0 \%$ and $33.8 \%$ of the seedlings planted at the harvested and unharvested sites, respectively, were dead, a nonsignificant difference $\left(\chi^{2}=2.26, \mathrm{df}=1, \mathrm{p}=0.13\right)$.

\section{DISCUSSION}

Combined rodent and insect predation yielded a range of $20 \%-27 \%$ of seeds preyed upon during the two years of study. A similar percentage (23.4\%) was found by Reis (1995) who made 800 seeds available to predators during 150 days in a forested area south of our study sites. It is important to note, 
however, that these figures may not represent the final predation pressure over a cohort of seeds since seeds continue to be preyed upon by rodents well beyond the fruiting season, even after germination (Reis, 1995; see also Notman \& Gorchov, 2001).

Although large frugivorous birds cross the intervening space separating the harvested and unharvested sites and deposit seeds in the former site (Galetti \& Aleixo, 1998), the influx of seeds there is minimal when compared to the unharvested site (M. A. Pizo, unpubl. data; see Study Site above). Given equal predator densities at both sites, this would represent a higher individual probability of a seed being preyed upon at the harvested site due to predator satiation occurring at the unharvested site. The combined predation caused by rodents and insects, however, did not differ between harvested and unharvested sites, thereby apparently contradicting our initial prediction. Only by looking separately at each class of predators could this issue be clarified. Rodent and insect seed predators responded differently to contrasting seed availability resulting from different harvesting regimes.

Although between-site differences in the amount of seed predation were not great, results showed that predation by rodents was more intense at the harvested site while insect attack predominated at the unharvested one. The lower rodentcaused predation observed at the unharvested site was probably a result of predator satiation rather than low densities of rodent populations. As generalist seed predators, rodents are unlikely to respond numerically to temporally abundant supplies of E. edulis seeds through either rapid population increase or long-distance seasonal movements (see Schupp, 1992). In fact, overall annual fruit production, which might limit the rodent population, does not differ between harvested and unharvested sites outside the fruiting period of E. edulis (Galetti, 1996), and population sizes of rodent species were not correlated with biomass of E. edulis seeds at the unharvested site (Vieira, 1999). Thus, population densities of small, terrestrial rodents are likely to be similar at both sites. As a consequence of the higher density of E. edulis seeds at the unharvested site, rodents became satiated, resulting in a proportional lower predation pressure there than at the harvested site. The significantly greater seed removal at the unharvested site in 1996 than in 1997 was probably determined by temporal fluctuations in rodent populations. The overall biomass of small rodents $(<300 \mathrm{~g})$ estimated in June 1996 was more than twice as great as in June 1997 (1.8 kg ha' ${ }^{-1}$ vs. $0.8 \mathrm{~kg} \mathrm{ha}^{-1}$; Vieira, 1999).

In contrast to the pattern observed for rodents, attack by insects predominated at the unharvested site. Specialist seed-eating insects tend to concentrate their activities in places where the density of their preferred seeds is higher (Hammond \& Brown, 1998). Coccotrypes scolytids are specialized in exploiting palm seeds (Janzen, 1972; Wood, 1982), thus the abundance of C. palmarum is possibly higher at the unharvested site, resulting in the higher predation levels observed there.

Early seedling survival appeared not to be related to seedling density, at least during the 1996 experimental period. Matos \& Watkinson (1998) found that the probability of E. edulis seedling survival decreased with increasing seedling density in a fragment of semideciduous forest in southeast Brazil, but these authors worked on a scale $(1 \times 1 \mathrm{~m}$ plots $)$ much smaller than ours. In such small plots competition may be a crucial factor in determining seedling survival (Pizo \& Simão, 2001). It should be noted, however, that seedling survival may vary from year to year (Schupp, 1990), and that mortality factors may act upon seedlings for longer than the six-month period in which we investigated. All of these claim for caution in generalizing our results to other areas bearing E. edulis populations. In any case, there is no obligatory linkage between seed and seedling predation (Houle, 1992; Schupp, 1995). Indeed, the differences observed in patterns of seed predation between harvested and unharvested sites may not hold for seedlings.

In conclusion, this study confirmed the dominance-predation hypothesis for the E. edulis population but only when we consider small, generalist rodent seed predators, and not specialized insect predators. This result shows that density-dependent mortality, not only at the individual level (Hammond \& Brown, 1998), but also at the population-level scale, is a function of the class of predators and their types of foraging behavior (see Cintra, 1997).

\section{Conservation implications}

Although the combined impact of the two classes of predators is similar between harvested and unharvested sites, we suspect that the predation verified in the former site has more drastic effects 
on the recruitment of the E. edulis population. Judging from the great input of seeds and the great amount of seedlings that annually cover the floor at the unharvested site, an oversupply of seeds appears to occur in relation to the availability of safe sites for development. In such situations, seed predators kill only excess seeds, with no serious consequence for the recruitment of the population (Andersen, 1989). At the harvested site, in contrast, population recruitment depends heavily upon the few seeds delivered via avian seed dispersal and likely coming from the neighboring unharvested site. However, because predators do not kill all the seeds that arrive and seedling survival during the critical period of the early months of development is comparable to that observed at the unharvested site, natural recovery and maintenance of the $E$. edulis population at the harvested site would be possible if the unharvested site were protected, and some harvesting control measures were applied.

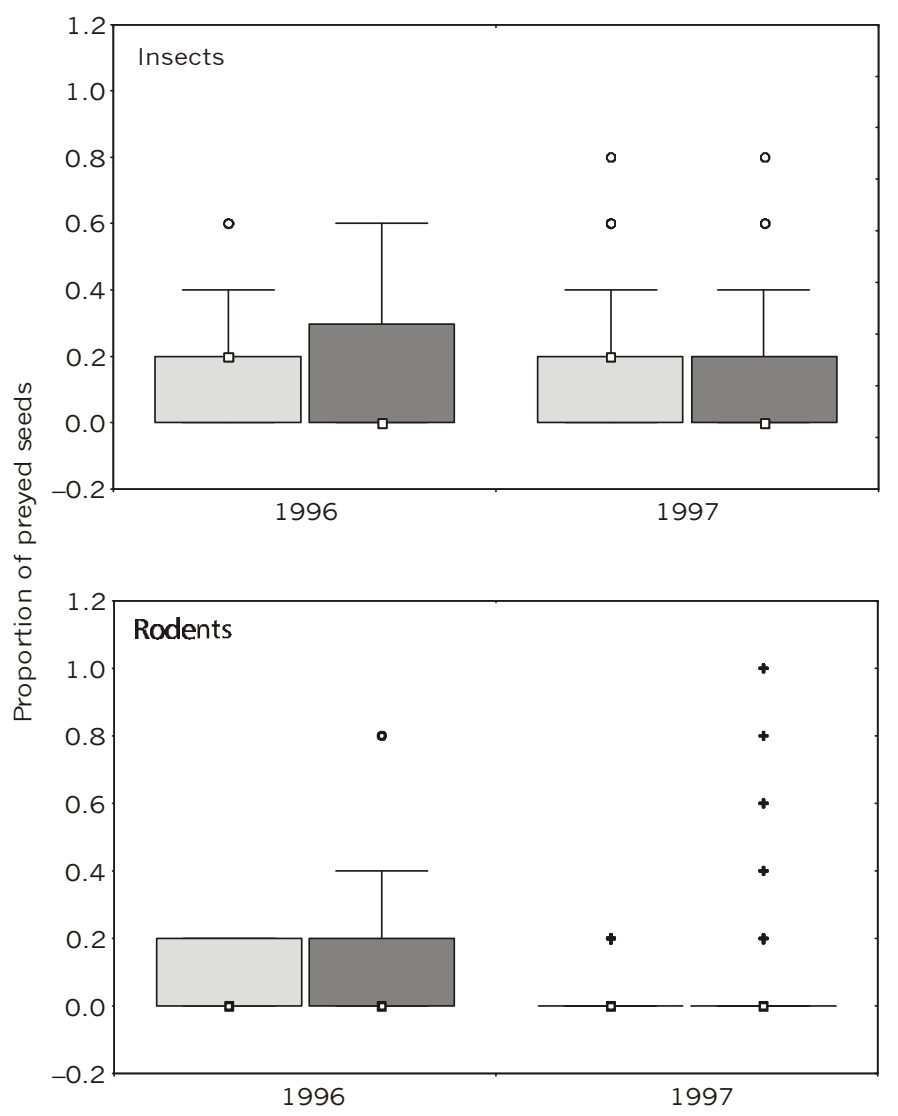

Fig. 1 - Box and whisker plots showing the proportions of Euterpe edulis seeds preyed upon by insects and rodents at the harvested (filled boxes) and unharvested (white boxes) sites in 1996 and 1997. Represented are medians (small squares), first-third quartile ranges (boxes), non-outlier ranges (set at $\pm 1.5 *$ the height of the box; vertical lines), outliers (circles), and extreme values (crosses). 
TABLE 1

Friedman block tests for the effects of harvesting and year on the proportion of Euterpe edulis seeds preyed upon by rodents and insects. Significant results (i.e., $p \leq 0.05$ ) are underlined.

\begin{tabular}{|l|c|c|c|c|c|c|c|c|c|}
\hline \multirow{2}{*}{ Test } & \multirow{2}{*}{ Effects } & \multicolumn{4}{|c|}{ Rodent predation } & \multicolumn{4}{c|}{ Insect predation } \\
\cline { 2 - 11 } & df & $\begin{array}{c}\text { Mean } \\
\text { square }\end{array}$ & F & p & df & $\begin{array}{c}\text { Mean } \\
\text { square }\end{array}$ & F & p \\
\hline $\begin{array}{l}\text { Harvesting } \\
\text { when blocked } \\
\text { by year }\end{array}$ & Harvesting & 1 & 2891.20 & 4.19 & $\underline{0.04}$ & 1 & 5236.00 & 5.30 & $\underline{0.02}$ \\
\cline { 2 - 11 } & Error & 238 & 689.56 & & & 238 & 987.90 & & \\
\hline $\begin{array}{l}\text { Year when } \\
\text { blocked by } \\
\text { harvesting }\end{array}$ & Year & 1 & 5170.50 & 7.37 & $\underline{0.007}$ & 1 & 133.50 & 0.14 & 0.71 \\
\cline { 2 - 11 } & Error & 238 & 701.17 & & & 238 & 978.11 & & \\
\hline
\end{tabular}

Sowing E. edulis seeds in areas where natural stands have been depleted has been done by local farmers to recover natural populations of $E$. edulis. Such seeds, sown in areas of low E. edulis density, may suffer severe predation by rodents (and, to a lesser extent, by insects) in the long run. Thus, albeit more expensive and time-consuming, planting of seedlings should be considered, in conjunction with protection from illegal extraction, for a more efficient recovery strategy (see also Nodari et al., 2000).

Acknowledgements - We are grateful to the Fundação Florestal do Estado de São Paulo, especially to Kátia R. Pisciotta, for making possible our work at Parque Intervales. The manuscript was greatly improved by comments from Pierre-Michel Forget, Graham N. Harrington, Andrew Henderson, Valesca B. Zipparro, Mauro Galetti, and L. Patrícia C. Morellato. Cláudia V. Ienne provided valuable help in the field. The field work was conducted while MAP and EMV were receiving fellowships from FAPESP (n. 95/2409-3) and CNPq, respectively. Data analysis was benefited by laboratory facilities provided by FAPESP at UNESP/ Rio Claro (n. 95/0269-6).

\section{REFERENCES}

ALEIXO, A., 1999, Effects of selective logging on a bird community in the Brazilian Atlantic Forest. Condor, 101: 537-548.

ALMEIDA-SCABBIA, R. J., 1996, Fitossociologia de um trecho de Mata Atlântica no Sudeste do Brasil. Master thesis, Universidade Estadual Paulista, Rio Claro, Brazil.

ANDERSEN, A. N., 1989, How important is seed predation to recruitment in stable populations of long-lived perennials? Oecologia, 81: 310-315.

BAWA, K. S. \& SEIDLER, R., 1998, Natural forest management and conservation of biodiversity in tropical forests. Cons. Bio., 12: 46-55.
BOONSTRA, R. \& CRAINE, I. T. M., 1986, Natal nest location and small mammal tracking with a spool and line technique. Can. J. Zool., 64: 1034-1036.

BOUCHER, D. H., 1981, Seed predation by mammals and forest dominance by Quercus oleoides, a tropical lowland oak. Oecologia, 49: 409-414.

CINTRA, R., 1997, A test of the Janzen-Connell model with two common tree species in Amazonian forest. J. Trop. Ecol., 13: 641-658.

CLARK, D. B., 1996, Abolishing virginity. J. Trop. Ecol., 12: 735-739.

COLLAR, N. J., GONZAGA, L. P., KRABBE, N., MADROÑO NIETO, A., NARANJO, L. G., PARKER, T. A. \& WEGE, D. C., 1992, Threatened birds of the Americas: the ICBP/ IUCN red data book. International Council of Bird Preservation, Cambridge.

DRANSFIELD, J., JOHNSON, D. \& SYNGE, H., 1988, The palms of the world: a conservation census. IUCN, Cambridge, 1150p.

EMMONS, L. H. \& FEER, F., 1997, Neotropical rainforest mammals: a field guide. The University of Chicago Press, Chicago, 281p.

FARIA, D. M., 1996, Uso de recursos alimentares por morcegos filostomídeos fitófagos na reserva de Santa Genebra, Campinas, São Paulo. Master Thesis, Universidade Estadual de Campinas, Campinas, Brazil, 86p.

FORGET, P.- M., 1992, Seed removal and seed fate in Gustavia superba (Lecythidaceae). Biotropica, 24: 408-414.

GALETTI, M., 1996, Fruits and frugivores in a Brazilian Atlantic forest. Ph.D Thesis, Cambridge University, Cambridge, 242p.

GALETTI, M. \& ALEIXO, A., 1998, Effects of palm heart harvesting on avian frugivores in the Atlantic rain forest of Brazil. J. Appl. Ecol., 35: 286-293.

GALETTI, M. \& CHIVERS, D. J., 1995, Palm harvest threatens Brazil's best protected area of Atlantic forest. Oryx, 29: 225226. 
GALETTI, M. \& FERNANDEZ, J. C., 1998, Palm heart harvesting in the Brazilian Atlantic forest: changes in industry structure and the illegal trade. J. Appl. Ecol., 35: 294-301.

GALETTI, M., MARTUSCELLI, P., OLMOS, F. \& ALEIXO, A., 1997, Ecology and conservation of the jacutinga Pipile jacutinga in the Atlantic forest of Brazil. Biol. Cons., 82: 31-39.

GALETTI, M., ZIPPARRO, V. B. \& MORELLATO, P. C., 1999, Fruiting phenology and frugivory on the palm Euterpe edulis in a lowland Atlantic forest of Brazil. Ecotropica, 5: 115-122.

HAMMOND, D. S. \& BROWN, V. K., 1998, Disturbance, phenology and life-history characteristics: factors influencing distance/density-dependent attack on tropical seeds and seedlings, pp. 51-78. In: D. M. Newbery, H. H. T. Prins \& N. Brown (eds.), Dynamics of tropical communities. Blackwell Science, London.

HENDERSON, A., GALEANO, G. \& BERNAL, R., 1995, Field guide to the palms of the Americas. Princeton University Press, Princeton, 352p.

HOULE, G., 1992, Spatial relationship between seed and seedling abundance and mortality in a deciduous forest of northeastern North America. J. Ecol., 80: 99-108.

JANZEN, D. H., 1972, Association of a rainforest palm and seed-eating beetles in Puerto Rico. Ecology, 53: 258-261.

KEY, G. E. \& WOODS, R. D., 1996, Spool-and-line studies on the behavioral ecology of rats (Rattus spp.) in the Galápagos islands. Can. J. Zool., 74: 733-737.

LAPS, R. R., 1996, Frugivoria e dispersão de sementes de palmiteiro (Euterpe edulis, Martius, Arecaceae) na Mata Atlântica, sul do estado de São Paulo. Master Thesis, Universidade Estadual de Campinas, Campinas, Brazil, 77p.

MANTOVANI, A. \& MORELLATO, L. P. C., 2000, Fenologia da floração, frutificação, mudança foliar e aspectos da biologia floral do palmiteiro, pp. 23-38. In: M. S. Reis \& A. Reis (eds.), Euterpe edulis Martius (palmiteiro): biologia, conservação e manejo. Herbário Barbosa Rodrigues, Itajaí, Brazil, 335p.

MATOS, D. M. S. \& WATKINSON, A. R., 1998, The fecundity, seed, and seedling ecology of the edible palm Euterpe edulis in southeastern Brazil. Biotropica, 30: 595-603.

McKEE, K. L., 1995, Mangrove species distribution and propagule predation in Belize: an exception to the dominance-predation hypothesis. Biotropica, 27: 334-345.

NODARI, R. O., FANTINI, A. C., REIS, A. \& REIS, M. S., 2000, Restauração de populações de Euterpe edulis Martius (Arecaceae) na Mata Atlântica, pp. 189-201. In: M. S. Reis \& A. Reis (eds.), Euterpe edulis Martius (palmiteiro): biologia, conservação e manejo. Herbário Barbosa Rodrigues, Itajaí, Brazil, 335p.
NOTMAN, E. \& GORCHOV, D. L., 2001, Variation in postdispersal seed predation in mature Peruvian lowland tropical forest and fallow agricultural sites. Biotropica, 33: 621-636.

PIZO, M. A. \& SIMÃO, I., 2001, Seed deposition patterns and the survival of seeds and seedlings of the palm Euterpe edulis. Acta Oecologica, 22: 229-233.

REIS, A., 1995, Dispersão de sementes de Euterpe edulis Martius (Palmae) em uma floresta ombrófila densa montana da encosta Atlantica em Blumenau, SC. Ph.D Thesis, Universidade Estadual de Campinas, Campinas, Brazil, 154p.

RODRIGUES, M., OLMOS, F. \& GALETTI, M., 1993, Seed dispersal by tapir in southeastern Brazil. Mammalia, 57 460-461.

SALLABANKS, R. \& COURTNEY, S. P., 1992, Frugivory, seed predation, and insect-vertebrate interactions. Ann. Rev. Entomol., 37: 377-400.

SCHUPP, E. W., 1988, Seed and early seedling predation in the forest understory and in treefall gaps. Oikos, 51: 71-78.

SCHUPP, E. W., 1990, Annual variation in seedfall, postdispersal predation, and recruitment of a neotropical tree. Ecology, 71: 504-515.

SCHUPP, E. W., 1992, The Janzen-Connell model for tropical tree diversity: population implications and the importance of spatial scale. Am. Nat., 140: 526-530.

SCHUPP, E. W., 1995, Seed-seedling conflicts, habitat choice, and patterns of plant recruitment. Am. J. Bot., 82: 399-409.

SIQUEIRA, M. F., 1994, Análise florística e ordenação de espécies arbóreas da Mata Atlântica através de dados binários. Master Thesis, Universidade Estadual de Campinas, Campinas, Brazil, 143p.

SMITH, T. J., III., 1987, Seed predation in relation to tree dominance and distribution in mangrove forests. Ecology, 68: 266-273.

SMITH, T. J., III, CHAN, H. T., MCIVOR, C. C. \& ROBBLEE M. B., 1989, Comparisons of seed predation in tropical, tidal forests from three continents. Ecology, 70: 146-151.

SOKAL, R. R. \& ROHLF, F. J., 1981, Biometry. 2nd edition, W. H. Freeman and Company, New York, 859p.

VIEIRA, E. M., 1999, Estudo comparativo da comunidade de pequenos mamíferos em duas áreas de Mata Atlântica situadas em diferentes altitudes no Sudeste do Brasil. Ph.D Thesis, Universidade Estadual de Campinas, Campinas, Brazil, 129p.

WOOD, S., 1982, The bark and ambrosia beetles of North and Central America (Coleoptera: Scolytidae), a taxonomic monograph. Great Basin Naturalist Memoirs, 6: 1-1359. 